Revista de Lenguas para Fines Específicos

https://ojsspdc.ulpgc.es/ojs/index.php/LFE/index

\title{
The translation of actually as an expression of evidentiality: a corpus-based analysis
}

\author{
Cristina Cela Gutiérrez ${ }^{1}$ \\ Universidad de Las Palmas de Gran Canaria \\ Facultad de Traducción e Interpretación, Calle Pérez del Toro, 1, 35003, Las Palmas de Gran Canaria, Spain
}

\section{Article history \\ Paper received: 02 May 2018 \\ Paper received in revised form and accepted for publication: 30 October 2018}

\section{Keywords}

Speaker's attitude, evidentiality, adverbs, translation of evidentiality, Linguistic Corpus CLUVI

\author{
ABSTRACT
}

Evidential markers in the form of adverbs are one of the most important and useful tools languages possess to modify the meaning of propositions adding authorial stance at word or sentence level. The expression of evidentiality, described as an indicator of to know what we know, i.e. the indication of how the speaker has obtained the information or acquired knowledge, varies considerably from one language to another by virtue of the cultural background in which a text is produced. At this point, the translation of evidentiality is of particular relevance in order to compare how other languages express the speaker's implication or impartiality in the proposition.

This study is based on the translation of "actually" as an evidential adverb to express authorial stance through a corpus-based translation analysis. To this end, I have analysed the multilingual UNESCO Corpus, a subcorpus within the Linguistic Corpus of the University of Vigo (CLUVI), to examine the entries offered for actually in its collection of scientifictechnical texts and determine which translation strategy has been regarded as an equivalent in the target texts. After the analysis of the corpus, I conclude that it is not possible to stablish an equivalence neither in the translation of the evidentials nor in the use of translation strategies, what means that every language has its own way and method to either lexically or grammatically highlight the source of the information available for the speaker.

\section{RESUMEN}

Los marcadores evidenciales en forma de adverbios son una de las herramientas más útiles que posee toda lengua para modificar el significado de sus enunciados y reflejar la actitud del hablante tanto a nivel léxico como semántico. La expresión de la evidencialidad, descrita

\section{Evidencialidad, En realidad, Estrategias de traducción, Corpus divulgativo de textos científico- técnicos \\ Palabras clave}$$
1
$$

\section{Corresponding author·Email: cristina.cela@ulpgc.es}

The article is a revised, much-extended version of our presentation at the 2nd Innovative and Creative Education and Teaching International Conference in Badajoz, Spain, on June 21, 2018. 
como un indicador de "saber lo que sabemos", es decir, la indicación de cómo el hablante ha obtenido la información o adquirido el conocimiento, varía considerablemente de una lengua a otra en relación al contexto cultural en el que se ha producido el texto. En este punto, la traducción de la evidencialidad cobra especial relevancia como mecanismo para comparar como las lenguas expresan la implicación o imparcialidad del hablante en los enunciados.

Este estudio se basa en la traducción de "actually" como un adverbio evidencial para expresar la postura del autor a través de un estudio de traducción basado en un corpus. Para este fin, he analizado el corpus multilingüe UNESCO, un subcorpus dentro del Corpus de Lingüística de la Universidad de Vigo (CLUVI), con el fin de examinar las entradas de "actually" en su colección de textos científico técnicos y determinar qué estrategias de traducción se han empleado como equivalente en sus textos meta.

Después del análisis del corpus, concluyo que no es posible establecer una equivalencia, ni en la traducción de los marcadores evidenciales, ni en el uso de las estrategias de traducción, lo que significa que cada lengua tiene su propia manera y método de reflejar el origen de la información disponible para el hablante tanto a nivel léxico como gramatical.

\section{Introduction}

The attitude of the speakers towards certain aspects can be shown in various ways, ranging from a simple grimace to the use of lexical items expressing what is in their mind. Evidentiality as a stance marker of to know how we know, i.e. to indicate the way the speaker has obtained the information or acquired knowledge, has arouse great interest in the linguistic community (Chafe and Nichols 1986, Aikhenvald 2006, Marshall 2015, Alonso-Almeida 2015).

Evidentiality is quite a complex concept in linguistics, as scholars do not seem to agree as to the exact nature of evidentiality, namely a grammatical marker or a lexical item, its status as an independent concept or a subcategory of epistemic modality, and its functions, among other matters. Broadly speaking, evidentiality is related to the way in which source/mode of knowledge is conveyed.

In many languages, the origin of the information is either lexically or grammatically highlighted in their utterances. Every language has a considerable variety of resources to refer to the source of information available for the speaker or the way the speaker has accessed to the information. In this way, evidentiality can be defined as the semantic domain related to express the source of information formulated in a statement.

In this study, I analyse the manifestation of the source of knowledge through the use of actually as an evidential marker, which may convey certainty as well as perspective. We argue that the use of evidentials might be culture-related, and so shift from one language to another in this regard can be by virtue of the cultural setting in which a text is produced. In this respect, the translation of adverbs gains special importance, as adverbs are suitable for the specification of the speaker's perspective in the three languages under study, namely Spanish, French and English.

\section{Methodology}


For this paper, I have analysed actually as an evidential adverb, which is studied in the framework of the multilingual UNESCO Corpus, a subcorpus within the Linguistic Corpus of the University of Vigo (CLUVI) to explore the frequency of use and function of actually in the source texts (ST) in English and how it has been translated into Spanish and French, as target languages (TT), in order to determine which translation strategy has been used in each particular case.

This paper is structured as follows. First, an introduction that describes the main objectives. Then, the methodology to carry out is exposed, focusing on the description of the corpus selected for my analysis. The theoretical section will be dedicated to the definition of the evidential adverbs and the classification of translation strategies following Vinay and Darbelnet's pioneering work Stylistique comparée du français et de l'anglais (1958). Once the analysis is carried out, results and findings will be presented and finally conclusions will be drawn.

\subsection{Corpus description}

As defined by Corpas Pastor (1995: 216), "a corpus is a collection of texts, each of which is translated into one or more languages than the original". A parallel corpus is considered a reliable source of information and a useful learning tool for students, translators and researchers, given that they enable to gather interesting information about the translative behavior from a contrastive approach.

Considering that my study is based on a comparative analysis of data and pretends to establish a contrast between languages by identifying differences from an empirical approach, I have selected the UNESCO Corpus included in the Linguistic Corpus of the University of Vigo (CLUVI).

The UNESCO Corpus of English-Galician-French-Spanish scientific-technical divulgation, which is one of the twenty-one corpus included in the CLUVI compilation. This corpus owes its name to the UNESCO Courier and, besides, it is the source of material supply that compounds the texts aligned in the UNESCO Corpus. This online tool provides a search toolbar, which allows both simple one-word searches and more complex sequences of words. The results are displayed in a multilingual chart alongside information concerning the use of the terms in different thematic contexts and their translation into Galician, Spanish and French. The translation units in French and Spanish of the UNESCO Corpus for actually constitute the basic material of my analysis. The main objective of this work is to study the translation strategies used in the translation of actually in the target languages to express evidentiality in scientific and technical texts aimed at larger audiences, not only experts in those fields.

Following some of the criteria of corpus classification proposed by Torruella Casañas (2017:25), the UNESCO Corpus is classified as follows:

\begin{tabular}{lll}
\hline Parameter & Type of corpus & Details \\
Modality & Written & Texts of the UNESCO Courier \\
Register & Specialised & Scientific- technical texts \\
Period of time & Contemporary & Current material \\
\hline \multicolumn{2}{c}{ Revista de Lenguas para Fines Especificos 25.1 } \\
ISSN: 2340-8561
\end{tabular}




\begin{tabular}{lll}
\hline Temporality & Diachronic & Texts published in 1998, 1999, 2000 and \\
& & 2001 \\
Size & Large & $3,724,620$ entries \\
Number of languages & Multilingual & English, Spanish, French and Galician \\
\hline
\end{tabular}

Figure 1. Features of the UNESCO Corpus

\section{Theoretical Framework}

\subsection{Adverbs}

The main reason to choose adverb forms as the target devices of my analysis is based on the general idea that adverbials stand as one of the grammatical categories that most clearly contribute to the expression of interpersonal meaning (Biber and Finegan, 1998).

Despite the many theories that have attempted to provide a clear and appropriate response, it is obvious that the definition of adverbs and their classification raise problems and cause a conceptual confusion among the many grammarians and linguists who have tried to determine the nature and function of these words at a grammatical level. This is mainly due to their heterogeneity of morphological structures and the complexity of their uses and functions. As García Tejera (1984:183) explains:

[...] el adverbio es una de las categorías gramaticales más complejas con las que se han venido enfrentando los gramáticos de todos los tiempos. Esta complejidad [...] nace de una enorme heterogeneidad, que abarca tanto a la diversa procedencia de los adverbios como a sus formas, a sus funciones e incluso a los diferentes matices que presente su significación.

According to the definition given by the RAE (Real Academia Española) Dictionary, which is also parallel to those proposed by other authors such as Bello et al. (1981), Alarcos (1994), Fraser (1996) or Biber (1999), an adverb is:

\footnotetext{
Clase de palabras cuyos elementos son invariables y tónicos, están dotados generalmente de significado léxico y modifican el significado de varias categorías, principalmente de un verbo, de un adjetivo, de una oración o de una palabra de la misma clase.
}

Taking this definition into account, it can be said that adverbs perform a wide variety of functions, which makes it difficult to classify them as a single or homogeneous category. Adverbs are mainly classified in three major categories according to their function: circumstance, stance and linking adverbs as coined by Biber et. al (1999:763). On their part, Halliday et al. (2004:123ff) introduce a similar three-type classification: circumstantial or adjuncts, adverbs that add more information to the action or state of the clause, linking adverbs, conjunctive or conjuncts adverbs that function as connectors and text organisers, and finally, adverbs that indicate the speaker's attitude towards the information of the utterance are disjuncts or modal adverbs.

For the present study, specific attention is paid to actually as a stance adverb. Since stance adverbs have the function to express some evaluation of the clausal information, to modify the style or content of the whole clause or a part of it and indicate the source of information and knowledge. Other authors speak about adverbs that indicate "conviction and some degree of doubt" (Quirk et al. 1985), "shade 
of doubt or certainty and perception of the state of affairs" (Greenbaum 1969) or "surely-adverbials and maybe-adverbials" (Biber and Finegan 1988,1989). All these adverbial forms indicating doubt or certainty in the clause, have been classified by Biber et al. (1999) under the name of epistemic stance adverbs. Additionally, they divide them into two major categories: adverbs that indicate degree of certainty and adverbs that express the source of information. In words of Hyland (2005), stance adverbs clearly indicate the author's attitude towards their texts, and their use depends on the effect the author desires to cause on the reader.

Furthermore, Biber et al. (1999:854-856) classify epistemic stance adverbials in six subtypes according to their semantic categories:

\begin{tabular}{|l|l|l|l|l|l|}
\hline $\begin{array}{l}\text { 1. Doubt and } \\
\text { certainty }\end{array}$ & $\begin{array}{l}\text { 2. Source of } \\
\text { knowledge }\end{array}$ & $\begin{array}{l}\text { 3. Actuality } \\
\text { and reality }\end{array}$ & 4. Limitation & $\begin{array}{l}\text { 5. Viewpoint } \\
\text { or } \\
\text { perspective }\end{array}$ & $\begin{array}{l}\text { 6. } \\
\text { Imprecision }\end{array}$ \\
\hline $\begin{array}{l}\text { Maybe, } \\
\text { probably, no } \\
\text { doubt }\end{array}$ & $\begin{array}{l}\text { Evidently, } \\
\text { apparently }\end{array}$ & $\begin{array}{l}\text { Actually, in } \\
\text { fact, really }\end{array}$ & $\begin{array}{l}\text { Generally, } \\
\text { mainly, } \\
\text { typically }\end{array}$ & $\begin{array}{l}\text { In my view, } \\
\text { from our } \\
\text { perspective }\end{array}$ & $\begin{array}{l}\text { Roughly, sort } \\
\text { of, like }\end{array}$ \\
\hline
\end{tabular}

Table 2: Subtypes of epistemic stance adverbials (Biber et al. 1999:854-856)

Actually as the adverb object of this study belongs to semantic category 3: actuality and reality. In the analysis of the excerpts described in section 4 of this paper the expression of stance will be discussed, as in some cases it is difficult to determine whether adverbs function as stance adverbials or as linking words.

The concept of evidentiality is directly related to stance and epistemic modality. Some researches even define evidentiality a subcategory of epistemic modality. However, here evidentiality and epistemic modality are considered as two different domains: "evidentiality refers to the reasoning processes that leads to a proposition, whilst epistemic modality evaluates the likelihood that this proposition is true" (Cornillie, 2009:47). For the purpose of this paper, I focus on the concept of evidentiality understood as the way the speaker expresses the source of information or knowledge supporting the proposition and the translation strategies used to find an equivalence at grammatical or lexical level in other languages.

\subsection{Translation strategies}

Since every language possesses specific linguistic and cultural particularities, the structure of the language entirely determines forms of thought and behaviour. Each language has a wide range of words and phrases to express the different aspects of human life, there is not a set of general rules that can be applied in a standardised and extensive manner. This fact makes the work of the translator complex and challenging, given that every language structures itself in a different way and following particular syntax and lexical rules. Moreover, during the translation process the translator must deal with style, idioms and proverbs, all of them requiring the proficiency of the source language (ST) and the target language (TT), ample translational skills and a good knowledge of the cultural aspects implicit in the working languages in order to find a suitable and accurate equivalence of the original message in the (TT). When it comes to the different solutions translators may find in order to transfer 
the meaning of the ST into the TT during the translation process, we refer to translation strategies. Lörscher (1991) defines translation strategy as "a potentially conscious procedure for solving a problem faced when translating a text, or any segment of it". However, many linguists and theorists have proposed other terms such as techniques, procedures or methods, which are simply synonyms for strategy. Despite the lack of homogeneity in the use of the concept, all of them describe the mental processes carried out by the translator when transferring a text from one language into another. In this paper, I will use the concept of translation strategy to refer to those techniques or methods used by the translator in order to solve translation problems, enabling the delivery of an accurate translation that keep the idiosyncrasies of the TL and reader.

Most theorists share the idea that translation strategies are divided into two categories: literal translation and free translation. Literal translation focuses on the lexical level, while free translation goes beyond words including culture-specific elements, that enhances the naturalness of the TT. Although, this initial distinction has been always the central issue of discussion among researchers, the concepts of literal and free translation were first proposed by Vinay and Darbelnet in 1958 in their pioneer work Stylistique comparée du français et de l'anglais, a contrastive analysis of French and English translations at stylistic level, which was released in English in 1995 with the title Comparative stylistics of French and English: a methodology for translation. This book represents a reference manual in the linguistic community and has served as the basis for later taxonomies of translation strategies.

The analysis of the present paper is based on Vinay and Darbelnet's classification of translation strategies (1958). They proposed two large groups (direct and oblique translations), containing seven translation strategies under the coined name "procédés techniques de la traduction". The following table represents the classification of the two categories and their corresponding translation strategies:

\begin{tabular}{|l|l|}
\hline Direct translation & $\begin{array}{l}\text { - Borrowing } \\
\text { - Calque } \\
\text { - Literal Translation }\end{array}$ \\
\hline Oblique translation & $\begin{array}{l}\text { - Transposition } \\
\text { - Modulation } \\
\text { - Equivalence } \\
\end{array}$ \\
\hline
\end{tabular}

Table 3: Vinay and Darbelnet's translation strategies (1995:30-42)

These translation procedures are defined as follows:

(1) Borrowing: A word from the ST is directly transferred to the TT, that is, a word from another language is adopted in the TT without changing its original form. (E.g.: business, running, light).

(2) Calque: it is a particular kind of borrowing where the ST word or phrase is literally translated wordfor-word. (E.g.: el momento de la verdad/the moment of truth / le moment de la vérité).

(3) Literal translation: it is a "word-for-word" of the ST into the TT. (E.g.: I left my spectacles on the table downstairs > J'ai laisse mes lunettes sur la table en bas). 
(4) Transposition: it implies the replacement of a word class of one part of the speech for another without changing the original message. (E.g.: he drives carelessly > su forma de conducir es irresponsable).

(5) Modulation: it involves a variation in the form of the original message by modifying the point of view although the meaning remains the same. (E.g.: it is not difficult > it is easy).

(6) Equivalence: this concept refers to cases where languages describe the same situation by different stylistic or structural means. Commonly used with idioms, proverbs and onomatopoeia. (E.g.: the car must have cost him an arm and a leg > el coche debió costar un ojo de la cara).

(7) Adaptation: this strategy implies changing the cultural reference when the cultural-specific peculiarities of the ST do not exist in the target culture and they must be eliminated or replaced by other cultural- specific peculiarities appropriate in the TT. (E.g.: meatballs > falafel).

The selection of one or another translation strategy during the process of translation will render different final products, with different degrees of adequacy and accuracy in the TL.

In this paper, I focus my analysis on the translation strategies used for the translation of actually in the TTs.

\section{Results and analysis}

After having interrogated the UNESCO Corpus introducing actually in its search toolbar, the sample obtained is quite representative, since there are 148 occurrences of actually as evidential marker in the UNESCO Corpus.

Actually is defined by the Oxford English Dictionary (OED) as "the truth or facts of a situation: really", (e.g.: in fact, from the above conclusions the truth is actually even more complicated) and also as an adverb in sentences in which there is information that is in some way surprising or the opposite of what most people would expect, (e.g.: it was actually a bit surprised that more people didn't agree with you). Actually is used to make reference to what is true or real and to accentuate that a statement is true, especially when it was believed or expected to be in a different way.

The Collins English Dictionary along with the unabridged dictionaries of French and Spanish, translates actually with the following adverbs and adverbial phrases in the Tाs:

(1) French: vraiment, réelement, en fait.

(2) Spanish: en realidad, realmente, exactamente.

Once every entry is analysed in its original context and its translation in the target languages, I determine that omission, literal translation, transposition and modulation are the translation strategies adopted for the translation of actually into Spanish and French. However, to these translation strategies it should be also mentioned several translation mistakes, which will be commented later in 
more detail. Out of the total amount of 148 entries, cases number 136 and 147 does not offer any translation in French.

Their frequency of use of every translation strategy in the total of 296 cases studied is represented in the figure below:

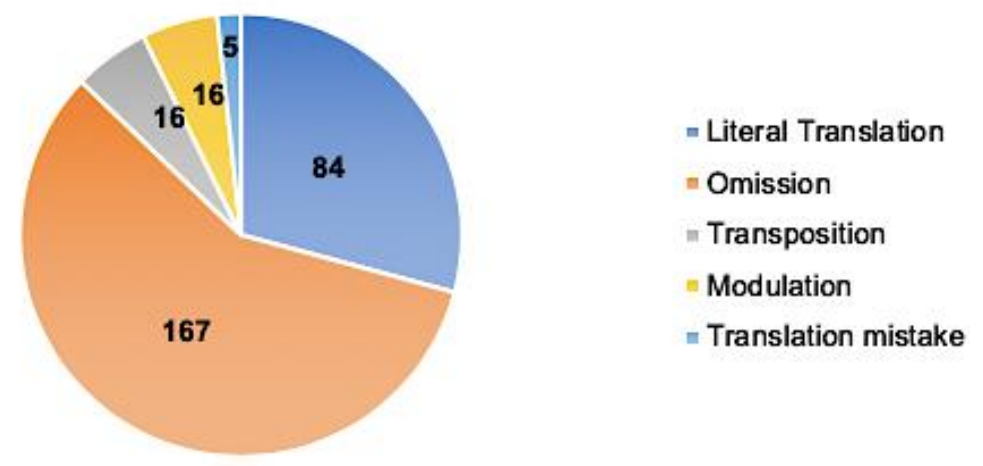

Figure 1: Translation strategies adopted for actually in Spanish and French

In Spanish, the most frequently used translation strategy is omission with a large amount of 81 cases of the 148 entries. Omission is followed by literal translation with a total of 43 cases, transposition with 10 cases, modulation with 8 cases and 3 translation mistakes. These data are represented in the following figure:

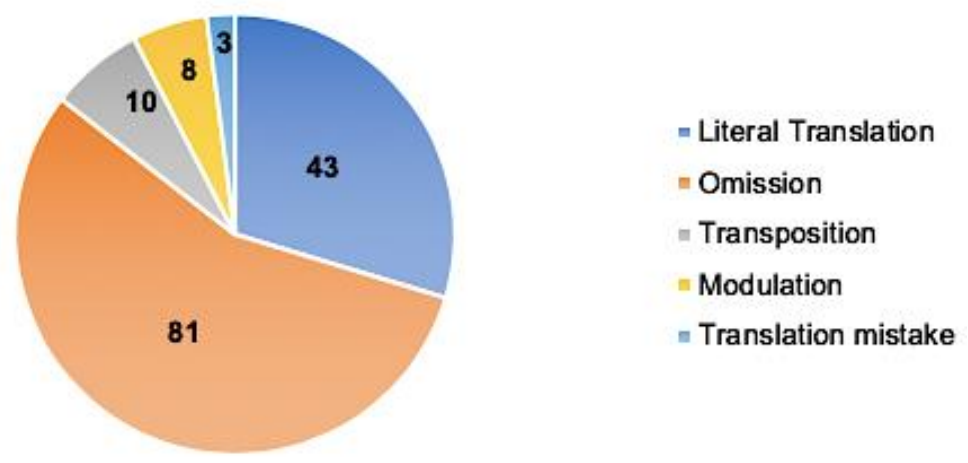

Figure 2: Translation strategies adopted for actually in Spanish

In French, the same translation strategies have been used, however, they differ slightly from Spanish. Out the 146 entries, omission has been used in 85 cases followed by literal translation with 41 cases, modulation with 8 , transposition with 6 and 2 translation mistakes. 


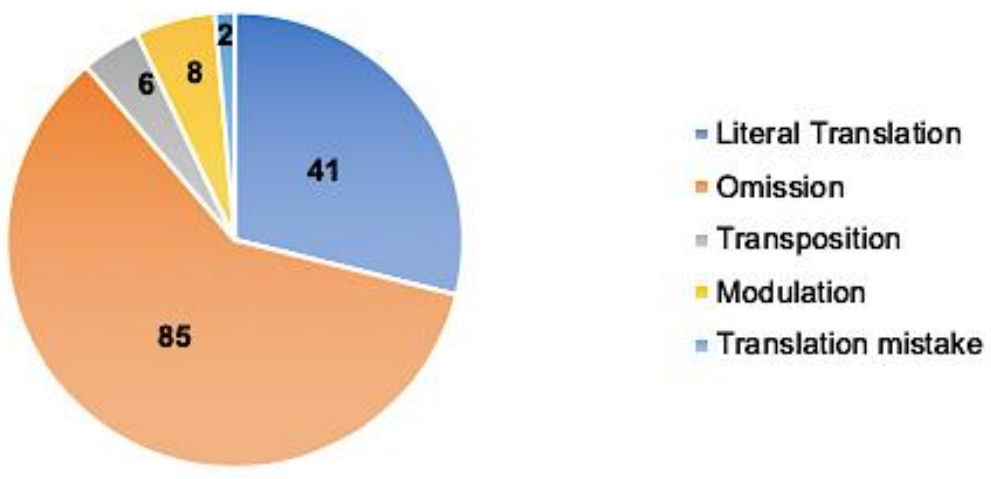

Figure 3: Translation strategies adopted for actually in French

In order to gain a better understanding of the use of the translation strategies analysed above for the particular case of actually, some of the cases retrieved from the UNESCO Corpus will be analysed:

Example 1:

\begin{tabular}{|l|l|l|}
\hline $\begin{array}{l}\text { English } \\
\text { (SL) }\end{array}$ & $\begin{array}{l}\text { Spanish } \\
\text { (TL) }\end{array}$ & $\begin{array}{l}\text { French } \\
\text { (TL) }\end{array}$ \\
\hline $\begin{array}{l}\text { Actually, it would be difficult to find } \\
\text { an anti-prohibitionist who would } \\
\text { advocate such a radical solution. }\end{array}$ & $\begin{array}{l}\text { Pero lo cierto es que ya nadie entre } \\
\text { los antiprohibicionistas propone una } \\
\text { solución tan radical. }\end{array}$ & $\begin{array}{l}\text { En réalité, il n'est plus guère } \\
\text { d'antiprohibitionniste pour prôner } \\
\text { une solution aussi radicale. }\end{array}$ \\
\hline Translation Strategies & MODULATION & LITERAL TRANSLATION \\
\hline
\end{tabular}

In Spanish, actually has been completely modified by making use of modulation. The original form has changed and thus altering the point of view. The coordinating conjunction "pero" is strategically placed at the beginning of the sentence and serves to introduce a contrasting idea. This initial position acts intensifying and adding more emphasis on the whole message. Pero is followed by an adjective phrase "lo cierto es que". The use of this phrase does not only change the message syntactically, but also stylistically, since the grammatical construction "it would be difficult" from the ST, which infuses a negative point of view into the whole message, has turned into lo cierto es, providing the message with a positive nuance.

In French, actually has been literally translated by the adverbial phrase "en réalité". By the use of literal translation, the original message is equally transferred into the target languages without causing a change in meaning and form.

Example 2:

\begin{tabular}{|l|l|l|}
\hline $\begin{array}{l}\text { English } \\
\text { (SL) }\end{array}$ & $\begin{array}{l}\text { Spanish } \\
\text { (TL) }\end{array}$ & $\begin{array}{l}\text { French } \\
\text { (TL) }\end{array}$ \\
\hline
\end{tabular}




\begin{tabular}{|l|l|l|}
\hline $\begin{array}{l}\text { A few stray reports acknowledged } \\
\text { this, but no national } \\
\text { newspaper actually put it on the front } \\
\text { page. }\end{array}$ & $\begin{array}{l}\text { Hubo pocos artículos informando } \\
\text { sobre ese fenómeno, pero en todo } \\
\text { caso ningún periódico de circulación } \\
\text { nacional lo destacó en primera plana. }\end{array}$ & $\begin{array}{l}\text { Quelques articles, ici et là, ont relaté le } \\
\text { phénomène, mais aucun quotidien } \\
\text { national n'en a fait sa première page. }\end{array}$ \\
\hline Translation Strategies & TRANSPOSITION & OMISSION \\
\hline
\end{tabular}

In the previous example, transposition has been the strategy adopted for the translation of actually in Spanish. There has been a shift in the word category. The noun phrase "en todo caso" serves, on the one hand, as a linking device between the two clauses occupying the initial position in the concessive clause, which is introduced by the linking conjunction "pero". And, on the other hand, it intensifies the propositional content and adds extra information.

In contrast, actually has not been translated in French, and no other elements have been used in any other part of the clause to compensate the lack of evidence supporting the proposition.

Example 3:

\begin{tabular}{|l|l|l|}
\hline $\begin{array}{l}\text { English } \\
\text { (SL) }\end{array}$ & $\begin{array}{l}\text { Spanish } \\
\text { (TL) }\end{array}$ & $\begin{array}{l}\text { French } \\
\text { (TL) }\end{array}$ \\
\hline $\begin{array}{l}\text { For instance, we are actually making } \\
\text { a profit on some of our online } \\
\text { courses. }\end{array}$ & $\begin{array}{l}\text { Por ejemplo, algunos de nuestros } \\
\text { cursos en línea en la actualidad nos } \\
\text { reportan beneficios. }\end{array}$ & $\begin{array}{l}\text { Par exemple, certains de nos cours en } \\
\text { ligne sont actuellement bénéficiaires. }\end{array}$ \\
\hline Translation Strategies & TRANSLATION MISTAKE & TRANSLATION MISTAKE \\
\hline
\end{tabular}

In this example, there has been a translation mistake due to the fact that the translator has literally transferred the English adverb form actually into Spanish and French. Actually is a clear case of deceptive cognate or false friend, a word or expression in one language that is often confused with a word in another language with a different meaning, because the two words look or sound similar. In words of Roca Varela (2011:80): "false friends are words in two languages that are similar in form but different in meaning". A lexical mistake in translation is a serious error that adversely affects the quality and accuracy of the TT and modifies the meaning of the original message, causing a different effect on the reader as the one desired by the original author.

Here, actually has been translated in the TTs as a circumstantial adverb expressing time, "en la actualidad" and "actuellement", whose meaning in English is "now, nowadays or at present". With that incorrect translation of the evidential marker, the message in the TTs differs significantly from the ST, acquiring a completely different perspective: evidence expression has been replaced by time expression, which does not even appear in the ST.

\section{Conclusion}

In the present work, I have studied the translation strategies applied for the translation in French and Spanish of actually as an evidential marker in the UNESCO Corpus. Based on the results analysed, actually tends to occupy a medial position in the clause aiming to express a contrary position or unexpected information. When actually occupies an initial position in the proposition, it is used to 
allude to what is true or real and to accentuate that a statement is true, especially when it was believed or expected to be in a different way. The translation strategies applied for the translation of actually coincide in French and Spanish, revealing quite similar figures. However, there were also found a few translation mistakes, i.e. false friends. This is due to the fact that its form looks and sounds similar in Spanish and French and the translator has opted for a transfer of the word into the TTs, instead of a translation with the equivalent forms, i.e. en realidad, realmente or en realité, réellement. In so doing, there is a mistake at a lexical level in the translation, which clearly changes the meaning of the original message and the effect on the reader. In addition, in those cases every possible evidence of the speaker's attitude towards the source of information has completely disappeared. It is also noteworthy, that the application of transposition and modulation in the translation of actually implies an amplification of the number words in the TTs and a variation in the sequence of the clause, clearly differing from the original.

\section{About the author}

Cristina Cela Gutiérrez is a part-time Lecturer in the Departmento de Filología Moderna, Universidad de Las Palmas de Gran Canaria. Her teaching subjects focuses on translation and interpreting in English and German. She has just presented her doctoral dissertation entitled "An Analysis of the Translation Strategies of the Evidential Adverbs in a CorpusBased Study". Her research interests include community interpreting, translation strategies, evidentiality, evidentials and the corpus-based translation studies. Since 2008 she has also worked as an official translator and interpreter in the language combination English, German and Spanish for the Home Affairs Spanish Ministry.

\section{References}

AIKHENVALD, A. Y. (2006). Evidentiality. Oxford: Oxford University Press.

ALARCOS, E. (1994). Gramática de la lengua española. Madrid: Real Academia Española: Espasa-Calpe.

ALONSO ALMEIDA, F. (2015). Introduction to Stance Language. Research in Corpus Linguistics, 3, 1-5.

ALONSO-ALMEIDA, F. (2015). On the mitigating function of modality and evidentiality. Evidence from English and Spanish medical research papers. Intercultural Pragmatics, 12, 33-57.

BELLO, A., AND TRUJILLO, R. (1981). Gramática de la lengua castellana (Ed. crítica de Ramón Trujillo ed.). Santa Cruz de Tenerife: Inst. Univ. de Lingüística Andrés Bello.

BIBER, D. (1988). Variation Acoss Speech and Writing. Cambridge: Cambridge University Press. 
BIBER, D. AND FINEGAN, E. (1988). Adverbial stance types in English. Discourse Processes: A Multidisciplinary Journal, 11(1), 1.

BIBER, D., JOHANSSON, S. AND LEECH, G. (1999). Longman Grammar of Spoken and Written English. London: Longman.

CHAFE, W. AND NICHOLS, J. (1986). Evidentiality: The linguistic coding of epistemology. Norwood, N.J.: Ablex.

Collins COBUILD English Dictionary, online <http://www.collinsenglishdictionary.com>.

CORNILLIE, B. (2009). Evidentiality and epistemic modality. On the close relationship between two different categories. Functions of Language 16(1), 44-62.

CORPAS PASTOR, G. (1995). The Role of Text Analysis in Corpus-Based Translation. In C. Valero Garcés, ed. Cultura sin fronteras. Encuentro en torno a la traducción. Madrid: Servicio de Publicaciones de la Universidad de Alcalá de Henares, 215-222.

FRASER, B. (1999). What are discourse markers? Journal of Pragmatics, 31(7), 931-952.

GARCÍA TEJERA, M. C. (1984). El adverbio en la tradición gramatical española. Gades 12, 183-206.

Greenbaum, S. (1969). Studies in English adverbial usage. London: Longman.

HALLIDAY, M. A. K. AND MATTHIESSEN, C. (2004). An introduction to functional grammar. London: Hodder Arnold.

HYLAND, K. (2005). Metadiscourse. Exploring Interaction in Writing. London: Continuum.

LÖRSCHER, W. (1991). Translation performance, translation process, and translation strategies: A psycholinguistic investigation. Tübingen: Gunter Narr Verlag.

MARSHALL, L. (2015). Evidential stance in translation: patterns of complementation in mediated memories. The translator, 21(1), 50-67.

QUIRK, R., GREENBAUM, S. LEECH, G. (1985). A Comprehensive Grammar of the English Language. London: Longman.

Oxford English Dictionary, online <http://www.oed.com/>.

TORRUELLA CASAÑAS, J. (2017). Lingüística de corpus: génesis y bases metodológicas de los corpus (históricos) para la investigación en lingüística. Frankfurt a.M.: Peter Lang.

Real Academia Española Dictionary, online <http://www.dle.rae.es>.

ROCA VARELA, M.L. (2011). Teaching and Learning False Friends: A Review of some Useful Resources. Encuentro Journal, 20, 80-87.

VINAY, Jean-Paul. \& DARBELNET, Jean. (1995). Comparative stylistics of French and English. Amsterdam: Benjamins.

VINAY, Jean-Paul., \& DARBELNET, Jean. (1958). Stylistique comparée du français et de l'anglais. Paris: Didier. 